\title{
The Making of a Historic District and the Economic Impact upon Housing Value: An Empirical Analysis of the Tree Streets Neighborhood in Johnson City, Tennessee
}

\author{
Ke Chen \\ Department of Political Science, International Affairs, and Public Administration, \\ East Tennessee State University, Johnson City, USA \\ Email: chenk@etsu.edu
}

Received September 18, 2013; revised October 18, 2013; accepted October 25, 2013

Copyright (C) $2013 \mathrm{Ke}$ Chen. This is an open access article distributed under the Creative Commons Attribution License, which permits unrestricted use, distribution, and reproduction in any medium, provided the original work is properly cited. In accordance of the Creative Commons Attribution License all Copyrights (C) 2013 are reserved for SCIRP and the owner of the intellectual property Ke Chen. All Copyright (C) 2013 are guarded by law and by SCIRP as a guardian.

\begin{abstract}
Many urban communities in the United States faced deteriorating physical infrastructure and social environment in the second half of the $20^{\text {th }}$ century. To restore such inner city neighborhoods, many neighborhoods have adopted historic preservation as a means to both aesthetically and fiscally improve the condition. This paper studies a historic district in the Tree Streets neighborhood, Johnson City, Tennessee in regard to its road toward historical preservation and neighborhood restoration. We find that through decades of a local civic organization's efforts and government planning initiatives, the community has successfully turned from a university slum into a livable neighborhood. We also find that the benefits are not strictly nostalgic but there is a positive economic impact of historic preservation designation on property values. The making of the historic district in the Tree Streets neighborhood both socially and economically has provided a great example of smart growth for Johnson city and other American cities to revitalize urban residential neighborhoods in central cities.
\end{abstract}

Keywords: Historic Preservation; Revitalization; Property Value

\section{Introduction}

In the second half of the $20^{\text {th }}$ century, many central-city neighborhoods in the United States struggled to define themselves as a desirable place to live and work, with a sustainable economic and social environment [1]. Faced with fleeing affluent city residents, deteriorating architecture and infrastructure, and declining tax base, both local and regional government agencies have endeavored to initiate comprehensive plans and develop strategies to bolster economic growth and encourage more efficient and sustainable urban environments. One important component of these strategies is the preservation and revitalization of historic districts, which aims primarily to sustain and create cultural values, including historical sites, cultural symbols, and the aesthetic and artistic qualities of architecture [2].

In the urban planning and design practice, designation of historic districts has been proved as an effective tool to preserve and revive inner-city neighborhoods [3-5].
From a policy perspective, restoration of old houses in a historic district by local governments to preserve the nostalgic feel of the "old days" in the city has made the place a more desirable destination for residents and shoppers [6]. Designation of historic preservation may also help boost the residential property values and increase the city's tax base [3,7-9]. In a broader context, historic preservation is becoming an integral component of smart growth program to curb urban sprawl and foster livable communities [5,10].

In this study, we take a close look at an urban residential area, the Tree Streets neighborhood, located in Johnson City, northeast Tennessee, to examine its road to become a historic district and the impact on residential property value brought out by such a change. Originally designed by famous planner John Nolen in the 1910s [11], the Tree Streets neighborhood, only two miles west of downtown Johnson City, processes a mixture of residential housing that is characteristic of the area in the 
early $20^{\text {th }}$ century. Similar to many other North American inner city communities in the 1970 s, the quality of the building structures deteriorated in the neighborhood and housing value went far below those in suburban subdivisions. It was even labeled a "university slum" by local residents, due to geographic proximity to a nearby university. In 1996 it was registered on the National Register of Historic Places, and later became part of Johnson City's downtown restoration plan. In this study, we aim to examine the forces that have changed the physical and social environment of residential areas in the Tree Streets neighborhood, with particular focus on the role of the civic engagement. We also attempt to understand the financial benefits brought out by these changes through examining the residential property value change before and after the designation of historic district, with a comparison to a non-historical residential neighborhood.

We find that through decades of concerted efforts of a local civic organization and government planning initiatives, the Tree Streets neighborhood has successfully turned from a university slum into a livable neighborhood: it has maintained the historic heritage, nurtured a sense of community, and enriched social interaction. We also find that the benefits are not strictly nostalgic, but there is a positive economic impact of historic preservation on residential property values. We believe that the making of the historic district in the Tree Streets neighborhood both socially and economically has provided a great example of smart growth for Johnson city and other American cities to revitalize central-city residential neighborhoods.

\section{Historic Preservation and Urban Planning}

Although early movement of historic preservation in the United States began in the latter half of the $19^{\text {th }}$ century, the institutionalization of such movement only became official when the National Historic Preservation Act was passed in 1966, partly in reaction to the widespread loss of historic places and growing environmental sensitivity in the preceding years [12]. The original concept was to protect individual sites of historic, cultural, and architectural significance. But gradually preservation movements incorporated urban structures adjacent to important sites as an integral component of the landscape. Preservationists came to the view that districts should be more encompassing, joining together a mix of buildings, streets, and open space to define the character of a historic district [13].

One important aspect of a historical district is that, located in central urban area, many have reflected the concept of sustainable neighborhoods characteristic of human-scale physical distance and frequent social contacts $[14,15]$. A desirable neighborhood unit, as suggested by
Perry (1929) [14], is defined by physical proximity, walkability, safe streets, and a pedestrian friendly environment [16]. This idea was echoed by planners and architects such as Andrés Duany and Elizabeth PlaterZyberk decades later in their ideas to develop sustainable neighborhoods and cities. The elements of diversity, mixed land use, and the sense of community in many historic districts are also found in the more recent concepts of new urbanism and smart growth, which respond to mass urban growth, traffic issues, and related problems in suburban neighborhoods in North America [5, 10,17-19].

On the other side, it is well known that traditional neighborhoods in historic districts suffered tremendous decline and de-investment in the mid- $20^{\text {th }}$ century [1], suggesting that the revitalization could be a long and financially consuming process. By law, individual home owners have no obligation to rehabilitate their houses. Designation of a historic district may impose restrictions and regulations on modification the structure of the buildings. It may also require maintenance of exterior ornamentation and other historic facade treatments over and above those required in the jurisdiction's general maintenance code [20]. Homeowners thus may feel an economic crunch from increased costs of renovating to specific standards [21]. As a result, new development might be deterred sometimes and revitalization halted for those with financial concerns [21].

One way to encourage renovation is through policy, and governments at various levels have used tax incentives to stimulate private preservation activities [2,21,22]. Since 1976, the Federal Historic Preservation Tax Incentive Program has allowed owners of historic properties to donate what is known as a facade conservation easement to a qualified charitable organization, to ensure that the architectural integrity of a historic property's exterior is maintained. The income tax deduction for this donation can be applied to the property owner's federal and state income tax returns [22].

Another important incentive for home owners to renovate old houses is the potential gain in economic value, incurred by increased residential property value after a historic district designation. Scholars have adopted different approaches to evaluate the economic impact of historic preservation in residential housing, including comparative studies of housing prices in the historic district and non-historic neighborhood [2,8,9,20,23], costbenefit analysis [7], and hedonic models that consider individual property values and neighborhood characteristics $[3,7]$. Most of these studies agree that property value has increased among historic districts after presservationist work is done.

Eventually, successful historic preservation programs that have achieved goals in both cultural preservation and 
economic development may provide great examples in the practice of modern preservation planning. They also offer effective lessons for smart growth programs in the efforts to re-develop central-urban areas and foster livable neighborhoods in many towns and cities throughout the country.

\section{Historic District in the Tree Streets Neighborhood, Johnson City, Tennessee}

Located in Johnson City, northeast Tennessee, the Tree Streets district is among the city's oldest communities. Designed by John Nolen in the turn of the $20^{\text {th }}$ century, the district possesses all the qualities by early planners as a traditional neighborhood unit, including its architectural design, street design, built environment, and the sense of community.

The district includes approximately 225 primarily residential structures built between 1900 and 1940. Major housing styles include Bungalows, American Foursquare, Colonial Revival, Queen Anne, L-Plan, and Tudor Revival houses (Figure 1). These early $20^{\text {th }}$ century architectures, particularly with aesthetic front porches, help to promote a great sense of community [16]. In addition to well-designed houses, streets are lined with trees and shrubs, contributing to a natural beauty and giving the district name "Tree Streets". These architectural and landscape design qualities have helped to account for the stability and popularity of the district through the years.

The lot size of houses in the district is fairly small and the relatively compact development makes for a greater population density. All houses are connected by sidewalks and the neighborhood is inherently walkable. Narrow roads and one-way traffic are designed to reduce automobile flow, and traffic circles in the intersection are laid out as a barrier for car passage [24]. The pedestrian friendly nature of the neighborhood encourages schoolage children to utilize the sidewalks and facilitates social interaction among residents. These characters of resident density, pedestrian permeability, and street life fit into a safe, livable urban space described by Jacobs in 1961 [25].

In the south side of the neighborhood, there is an elementary school: Southside School. While geographic proximity provides neighborhood residents convenience and saving in time and money, the location of school is also significant as it offers school children regular physical activity by walking to school [26]. Besides, and perhaps more importantly, walking and biking at an early age can help young children to develop healthy habits, and increase the likelihood that they will continue to use
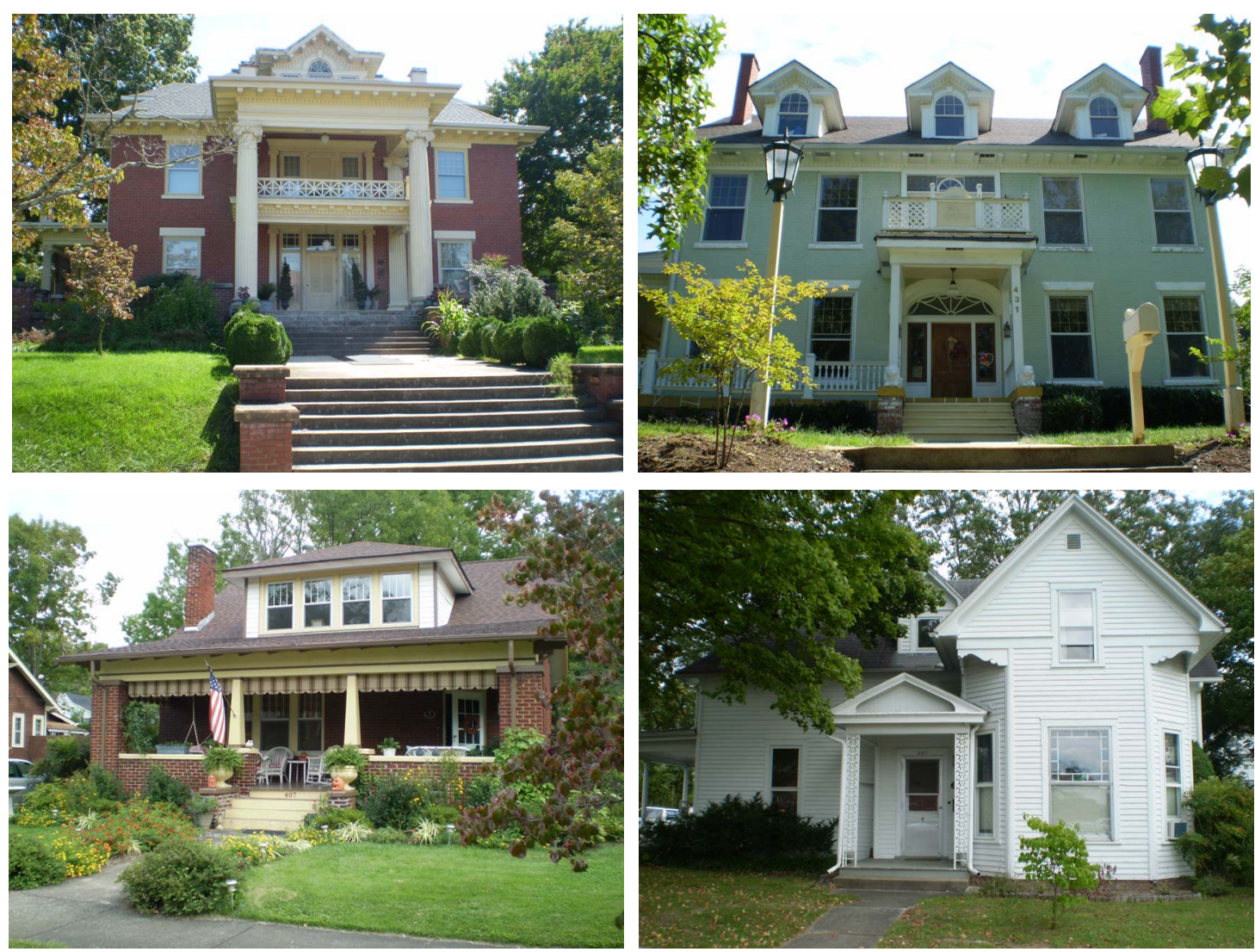

Figure 1. Mixed housing styles in Tree Street neighborhood. 
these modes of transportation later in life [26]. Overall, this elementary school is considered a key component of the Tree Streets district, as well as in other traditional neighborhood units [14].

Altogether, despite being a century old, the neighborhood possesses many essential qualities of new urbanism, which promotes walkable neighborhoods, narrow streets and slow traffic, higher density, mixed-use houses, and small but accessible playgrounds [19]. The neighborhood also fits into the picture of smart growth through advocating pedestrian-friendly land use in compact urban centers with neighborhood schools and complete streets [19].

\subsection{The Road to Historic Preservation: Civic Participation and Government Planning}

Like many other inner city neighborhoods in the United States, the Tree Streets neighborhood was plagued by social diseases such as drug and crimes in the 1960s and 1970s. As a response, the Southside Neighborhood Organization (SNO) was founded in the late 1970s as a non-profit organization with the intent of eradicating dreadful social behaviors, especially in and around an apartment complex which is located adjacent to Southside School [27]. During the 1980s, many of the large, historic buildings along the Tree Streets were being converted into apartment buildings for renting. This was viewed as having a negative impact upon property values and neighborhood stability. As a result of declining physical and social condition, the Tree Streets neighborhood was labeled a "university slum", as it is in proximity to East Tennessee State University nearby. SNO resurfaced from dormancy and petitioned the city to down-zone the area from R-3 (single and multifamily dwellings with median density) to R-2 (low density single family dwellings) [27]. This down-zoning in 1987 could force rooming houses to be converted back to single family dwellings if the property changed hands and remained vacant for at least six months.

The organization fought most significant battles in the early 1990s. During this time, much debate was taking place regarding the future of Southside School. At the time, the Southside School was in bad condition and the school board was considering closing the school. Residents, planning commissioners, and school board members alike were fighting fiercely for the school's future. If the school was to remain in its current location, it would have to be expanded by Tennessee law, which would require the acquisition of ten houses around the site -including that of a former SNO president. On the other hand, relocation of the school to an off-site place would be more cost effective, yet would arguably lead to neighborhood decline [27]. As mentioned previously, the existence of the school as a neighborhood anchor was a vital element in its original design. After much debate from all sides, members of SNO voted to support keeping the school at its current location and the Board of Education followed suit.

The work of SNO has successfully stabilized the neighborhood. Also through the residents' organization's efforts, the Tree Streets neighborhood was listed on the National Register of Historic Places in 1996. Three years later in 1999, Johnson City planners developed a Conservation Zoning Overlay for the neighborhood [28], a tool to ensure that the architecture and urban layout to be undamaged. Through these planning policies, overlay zones ensure structures and urban patterns are to be protected from alterations which would lessen their historic architectural relevance.

These actions by citizen's organization and the government plans have proved to be effective. They have improved the built environment and turned deteriorated places around. The image of decay, indifference and crime was turned into a sense of roots and a feeling of community pride [29]. Today, residents in the Tree Streets neighborhood enjoy well-restored historic buildings, walkable streets, and a much safer environment. In addition to physical restoration of the houses, the neighborhood hosts a variety of activities to enrich the community culture and enhance the recognition of the historic heritage. Such activities include music festivals that offer free folk music in the open space in the neighborhood, historic house tour that introduces the history of houses and the tales of the renovation progress, and an annual community-wide yard sale that fosters a sense of community [30]. The neighborhood also maintains a website to publish upcoming activities and keep residents informed of updated events.

All these civic engagement and the associated activities have made the Tree Streets neighborhood a unique charming community, where residents participate actively in a "street ballet" [25]. These also increase the collective stock of social capital - the expected economic benefits derived from cooperation between individuals and groups - that characterizes true communities as heralded by Putnam in 1995 [31]. Besides, they resonate essential ideas in new urbanism to strengthen the connection between people in their roles as neighbors and fellow citizens [19].

\subsection{The Impact of Preservation on Property Values after a Historic District Designation}

Civic participation, together with planning initiatives has helped to solidify the viable nature of the Tree Streets neighborhood. Then, how about property values? Have the houses appreciated with the improved living quality of the neighborhood? To answer this question, we randomly selected 50 residential houses along West Pine 
Street, located in the core of the Tree Streets neighborhood, to analyze the change in housing value before and after the designation of historic district in 1996. For comparison, we also randomly selected 50 non-historical residential houses along Seminole Drive, which is located two miles west of the Tree Streets Neighborhood and around four miles away from downtown.

We collected property tax records for the years 1992, 2006, 2000, 2005, and 2010 from Washington County Tennessee's trustee's office where the city of Johnson City is located. Washington County started publishing property appraisal values in 1992 and assesses properties every four years. Table 1 shows the basic statistics of housing values for the selected five years. In 1992, four years before the Tree Street Neighborhood was designnated as a historical district, the average appraised value for houses in West Pine Street was around \$37,900. In contrast, the value for houses in the non-historical Seminole Drive was averaged at $\$ 49,900$, a 32 percent higher than that in the West Pine Street. In the following years of 1996 and 2000, the average values in the West Pine Street increased significantly and the gap with the non-historical neighborhood was shortened. In the years 2005 and 2010, the average house value in the West Pine Street exceeded that along Seminole Drive.

When the property value growth rate is concerned, the West Pine Street properties presented a growth rate of 12.4\% between 1992 and 1996, the same as that in the non-historical Seminole Drive (Table 2). However, in the following period of 1996-2000, the average annual growth rate in the property value in West Pine Street was $8.7 \%$, while the number for the non-historical neighbor- hood was only $4.1 \%$. The West Pine Street properties continued high average annual growth rates of $6.4 \%$ and $6.3 \%$ in the following two time periods of 2000-2005 and 2005-2010 respectively. In comparison, the corresponding numbers for properties along non-historical Seminole Drive were $1.5 \%$ and $5.4 \%$.

Table 3 presents the $\mathrm{T}$ test results between average annual growth rates in two neighborhoods. There is no significant difference in the period of 1992 and 1996 before the Tree Streets neighborhood was designated as a historical district. In the following two five-year periods, the average growth rates in the West Pine Street were much higher than those in the non-historical neighborhood, and the difference is statistically significant at 0.0001 level. Between 2005-2010, the difference is significant at 0.1 level. These statistics suggest that, after 1996, the average growth rate in appraised property value in the West Pine Street has well exceeded that in a non-historical neighborhood along the Seminole Drive.

Local realtors with experience in selling Tree Streets properties offered some explanation of the accelerated housing value in the neighborhood [29]. Andrew Baxter of ERA/Golden Key Realty attributed the success of the neighborhood, as well as the significant appreciation in market value, to an increased pride in ownership. According to Baxter, when one homeowner renovates his or her property, a "snowball effect" tends to occur. Neighbors immediately adjacent to the renovated property will begin rehabilitation of their own properties and so on [29]. There is a seemingly competition among neighbors to make their own houses look good in the community. Therefore, the property value in the Tree Streets

Table 1. Basic statistics of appraised property value.

\begin{tabular}{cccccccccccc}
\hline & \multicolumn{3}{c}{$\begin{array}{c}\text { Houses in the historical district-Tree Street } \\
(\mathbf{N}=\mathbf{5 0} \text { in thousands of } \mathbf{)}\end{array}$} & \multicolumn{4}{c}{$\begin{array}{c}\text { Houses in a nearby non-historical district-Seminole Drive } \\
(\mathbf{N}=\mathbf{5 0} \text { in thousands of \$) }\end{array}$} \\
\hline Year & 1992 & 1996 & 2000 & 2005 & 2010 & 1992 & 1996 & 2000 & 2005 & 2010 \\
Mean & 37.9 & 60.9 & 83.9 & 114.4 & 156.5 & 49.9 & 79.7 & 93.3 & 97.5 & 127.2 \\
Minimum & 4.9 & 5.3 & 9.8 & 12.0 & 14.0 & 20.3 & 31.6 & 37.4 & 47.2 & 61.6 \\
Maximum & 125.2 & 238.8 & 260.4 & 196.8 & 261.2 & 125.2 & 238.8 & 260.4 & 196.8 & 261.2 \\
St. Dev. & 14.7 & 23.6 & 31.3 & 41.0 & 59.4 & 21.1 & 36.8 & 40.4 & 29.8 & 38.9 \\
\hline
\end{tabular}

Table 2. Average annual growth rate in appraised property value.

\begin{tabular}{ccccccccc}
\hline & \multicolumn{3}{c}{ Houses in historical district $\mathbf{( N = \mathbf { 5 0 , } \% )}$} & \multicolumn{2}{c}{ Houses in a nearby non-historical district $(\mathbf{N}=\mathbf{5 0 ,} \%)$} \\
\hline Year & $92-96$ & $96-00$ & $00-05$ & $05-10$ & $92-96$ & $96-00$ & $00-05$ & $05-10$ \\
Mean & 12.4 & 8.7 & 6.4 & 6.3 & 12.4 & 4.1 & 1.5 & 5.4 \\
Minimum & -2.2 & -0.0 & -1.8 & 1.7 & 2.8 & -1.3 & -16.2 & 3.6 \\
Maximum & 28.9 & 28.0 & 17.1 & 17.8 & 23.3 & 11.9 & 8.2 & 10.0 \\
St. Dev. & 5.3 & 5.3 & 3.7 & 3.0 & 3.9 & 2.7 & 4.8 & 1.1 \\
\hline
\end{tabular}


Table 3. $T$ test on average annual growth rate in appraised property value between historical district and non-historical neighborhood.

\begin{tabular}{ccccc}
\hline & $\mathbf{9 2 ~ - ~ 9 6}$ & $\mathbf{9 6 - 0 0}$ & $\mathbf{0 0 - 0 5}$ & $\mathbf{0 5}-\mathbf{~ 1 0}$ \\
\hline T value & 0.03 & -5.2 & -5.0 & -1.9 \\
P value & 0.97 & $<0.0001$ & $<0.0001$ & 0.06 \\
\hline
\end{tabular}

neighborhood has kept an above-average growth rate than other communities.

\section{Conclusions and Discussions}

This study of the Tree Streets neighborhood in Johnson City, northeast Tennessee focuses on the process and effect of historic preservation. We find that the making of this historic district mainly results from the efforts of the local civic organization, which is further enhanced by government planning initiatives. Through decades of concerted efforts, the Tree Streets neighborhood has successfully turned from a university slum into a livable neighborhood. It has maintained the historic heritage, stabilized the social condition, and nurtured a sense of community.

In addition, historic preservation has been effective to vitalize this urban area from an economic perspective. We find that after the Tree Streets neighborhood was designated as a historical district in 1996, residential houses there have displayed a higher growth rate in appraised property value than residential houses in a nearby non-historical community. The economic gains may further encourage potential restoration of old houses in the future.

The success of the Tree Streets neighborhood provides important implications on urban planning for Johnson City in terms of inner city renovation and development. Johnson City has begun to work towards smart growth to better utilize existing urban land. The preservation and revitalization of the Tree Streets neighborhood fits within this vision and offers a great example: the making of a livable neighborhood is a concerted effort from strong community based organizations and municipal policy support. In particular, a number of citizens that are active in community building and the governmental process are extremely important.

To expand from focus on Johnson City, our case study also provides a good example for balanced comprehensive planning with both social harmonization and the economic stability for towns and cities throughout the country, which is using New Urbanism and/or smart growth strategies to boost central urban residential areas. Our results demonstrate that preservation planning, which attempts to eliminate the social concerns of the degradation and improve the physical landscape of his- torically significant environments, is economically viable for central urban residential areas.

\section{REFERENCES}

[1] P. L. Knox and L. McCarthy, "Urbanization: An Introduction to Urban Geography," 3rd Edition, Pearson, 2012.

[2] R. Mason, "Reclaiming the History of Places," In: G. Hack, Ed., Local Planning, ICMA Publishing, Washington D.C., 2009.

[3] D. A. Ford, "The Effect of Historic District Designation on Single-Family Home Prices," Real Estate Economics, Vol. 17, No. 3, 1989, pp. 353-362. http://dx.doi.org/10.1111/1540-6229.00496

[4] D. E. Gale, "The Impacts of Historic District Designation: Planning and Policy Implications," American Planning Association. Journal of the American Planning Association, Vol. 57, No. 3, 1991, pp. 325-340. http://dx.doi.org/10.1080/01944369108975503

[5] T. Daniels and M. Lapping, "Land Preservation: An Essential Ingredient in Smart Growth," Journal of Planning Literature, Vol. 19, No. 3, 2005, pp. 316-329. http://dx.doi.org/10.1177/0885412204271379

[6] S. Cline, "Downtown Colorado Springs Reworks the Old to Fit in with the New," The Colorado Springs Business Journal, 2005.

[7] N. E. Coulson and R. M. Leichenko, "The Internal and External Impact of Historical Designation on Property Values," Journal of Real Estate Finance and Economics, Vol. 23, No. 1, 2001, pp. 113-124. http://dx.doi.org/10.1023/A:1011120908836

[8] J. Gelinas, "Preservationists Tout Value of Historic Districts in Aiken, SC," The Augusta Chronicle, 2004.

[9] N. E. Coulson and M. L. Lahr, "Gracing the Land of Elvis and Beale Street: Historic Designation and Property Values in Memphis," Real Estate Economics, Vol. 33, No. 3, 2005, pp. 487-507. http://dx.doi.org/10.1111/j.1540-6229.2005.00127.x

[10] A. Downs, "Smart Growth: Why We Discuss It More Than We Do It," Journal of American Planning Association, Vol. 71, No. 4, 2005, pp. 367-378. http://dx.doi.org/10.1080/01944360508976707

[11] Mariemont Preservation Foundation, 2012. http://www.mariemontpreservation.org/founding.htm

[12] S. Feigenbaum and T. Jenkinson, "Government Incentives for Historic Preservation," National Tax Journal, Vol. 37, No. 1, 1984, pp. 113-119.

[13] US/ICOMOS, "An Overview of Preservation in the United States," 2013. http://www.usicomos.org/preservation

[14] C. Perry, "The Neighborhood Unit," In: Neighborhood and Community Planning, Committee on the Regional Plan of New York and Its Environs, New York, 1929.

[15] K. Susan, "The Urban Neighborhood: A Sociological Perspective," Random House, Inc., New York, 1968.

[16] C. J. Hoch, C. D. Linda and F. S. So, "The Practice of Local Government Planning, Municipal Management Se- 
ries," International City/County Management Association, Washington, D. C., 2000.

[17] S. E. Wallace, "The Urban Environment," The Dorsey Press, Homewood, 1980.

[18] J. Weitz and T. Moore "Development Inside Urban Growth Boundaries: Oregon's Empirical Evidence of Contiguous Urban Form," Journal of the American Planning Association, Vol. 64, No. 4, 1998, pp. 424-440. http://dx.doi.org/10.1080/01944369808976002

[19] A. Duany, J. Speck and M. Lydon, "The Smart Growth Manual,” McGraw-Hill, New York, 2009.

[20] R. M. Leichenko, N. D. Coulson and D. Listokin, "Historic Preservation and Residential Property Values: An Analysis of Texas Cities," Urban Studies, Vol. 38, No. 11, 2001, pp. 1973-1987. http://dx.doi.org/10.1080/00420980120080880

[21] D. Listokin, B. Listokin and M. Lahr, "The Contributions of Historic Preservation to Housing and Economic Development," Housing Policy Debate, Vol. 9, No. 3, 1998, pp. 431-478. http://dx.doi.org/10.1080/10511482.1998.9521303

[22] J. M. Kearns, "Demystifying the Federal Historic Preservation Tax Incentive Program," The CPA Journal, Vol. 73, No. 3, 2003, p. 40.

[23] S. S. Munoz, "Preserving the Tract Home: Historic Districts on the Rise; To Boost Property Values, Owners Seek Designation; First Central AC in Phoenix," Wall Street Journal, 2006. http://online.wsj.com/article/SB114247655527199728.ht $\mathrm{ml}$
[24] D. Appleyard, "Livable Streets," University of California Press, Berkeley, 1981.

[25] J. Jacobs, "The Death and Life of Great American Cities," Random House, New York, 1961.

[26] D. C. Sloane, "Longer View: From Congestion to Sprawl: Planning and Health in Historical Context," Journal of the American Planning Association, Vol. 72, No. 1, 2006 , pp. 10-18. http://dx.doi.org/10.1080/01944360608976720

[27] M. P. Marchioni and L. S. Felker, "Neighborhood Associations and the Planning Process: The Case of the Southside Neighborhood Organization," In: P. J. Obermiller, Ed., Down Home, Downtown, Kendall/Hunt, Dubuque, 1996.

[28] City of Johnson City, Tennessee, "Historic Preservation Element Johnson City Comprehensive Plan," Planning Department, 2004.

[29] T. A. Lloyd, "Dollars and Sense: A Preliminary Investigation of Historic Preservation and Its Effects on the 'Tree Streets' Neighborhood of Johnson City, Tennessee," Master Thesis, East Tennessee State University, 2006.

[30] Tree Streets Neighborhood Organization, "Historic Southside Neighborhood Johnson City, TN," 2013. http://www.treestreets.net

[31] R. D. Putnam, "Bowling Alone: America's Declining Social Capital," Journal of Democracy, Vol. 6, No. 1, 1995, pp. 65-78. http://dx.doi.org/10.1353/jod.1995.0002 